Quaderni di Geografia Cahiers de Gécongaty rataphie

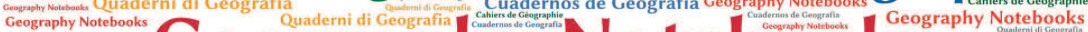
Cuadernos de Geografia Geography Notebooks $U 201000$ Cahiers de Géographi Cahiers de Géographie cahiers de Géographie Cuadernos de Geografía Cahiers de Géographie Cahiers de Géographie Cuadernos de Geografía Geography Notebooks

\author{
$4(2021)$ \\ 1 \\ Teatro di suoni. \\ Spazi acustici teatrali e territoriali
}

A cura di

Martino Mocchi, Lorena Rocca, Demis Quadri and Carlotta Sillano

EDITORIAL

Teatro di suoni per l'attaccamento ai luoghi. Uno sguardo geografico 11

Lorena Rocca

Per un teatro di suoni. Riflessioni su possibili dimensioni sonore nelle 23 creazioni site-specific di physical theatre

Demis Quadri

INTRODUCTION

Teatro di suoni. Spazi acustici teatrali e territoriali

Demis Quadri e Lorena Rocca

SPECIAL Issue

I suoni di Mantova come strumenti di interpretazione del paesaggio.

Tra turismo sostenibile ed educazione al patrimonio culturale

Valeria Pecorelli, Franca Zuccoli, Alessandra De Nicola, Enrico Squarcina

Il paesaggio sonoro campano tra contemporaneità e nuove forme

di progettualità turistica

Germana Citarella 
La narrazione spettacolarizzata del paesaggio sonoro.

Da Giuseppe Chiari a Philip K. Dick e oltre

Francesco Michi

Musica di paesaggi sonori. Enunciazione, risignificazione, comunicazione

Carlotta Sillano

Camminare per ascoltare. Partiture invisibili del territorio abitato

Elisabetta Senesi

Il paesaggio sonoro in relazione. Suono, movimento e immagini per stimolare complessità percettiva Angela Calia

Groove Fields. Understanding the Dance Floor from an Art-Based Research Perspective

Sebastian Mattbias

Il silenzio come esperienza trasformativa. L'importanza del silenzio nella meditazione e in ambito professionale

Sebastiano Caroni

Progettare il silenzio. Una lettura acustica dell'ex villaggio sanatoriale 125 Morelli a Sondalo

Martino Mocchi

Voicing One's Will. Theatre as Audio-Visual Hypotyposis of the Poetic

Michael Groneberg

Music and Clowning in Europe, 20th-21st centuries

Anna Stoll Knecht

Il paesaggio sonoro nella composizione musicale. Un percorso bibliografico

Stefano Alessandretti

\#exploreART: il labirinto di A. Pomodoro e i bambini. Un progetto di fruizione condivisa con percorsi sensoriali partecipati Alessandra De Nicola, Franca Zuccoli 


\section{OTHER EXPLORATIONS}

Il rumore lontano. Intervista a Lorena Rocca

a cura di Martino Mocchi

Re Cervo. Intervista a Antonella Astolfi

a cura di Krizia Bonaudo e Demis Quadri

Centovalli-Centoricordi. Intervista a Oliviero Giovannoni a cura di Krizia Bonaudo e Demis Quadri

Alla ricerca di un metodo: Open Space Technology 



\title{
Voicing One's Will. Theatre as Audio-Visual Hypotyposis of the Poetic
}

\author{
Michael Groneberg \\ Université de Lausanne, Faculty of Arts, Department of Philosophy \\ DOI: https://doi.org/10.7358/gn-2021-001-gron
}

\begin{abstract}
This contribution invites the reader on a conceptual and imaginary journey through the relation between the visual and auditive dimensions of theatre. A reading of Ovid's metamorphosis of Hermaphroditus and Salmacis will illustrate the general idea which I will then confront with the recent proposal of Denis Guénoun to conceive of theatre as the (visual) hypotyposis of poetry. Hegel and others will serve as the catalyst potion to allow for a union of the two lines of thought, leading to the conclusion that theatre is not only a visual but also an auditive hypotyposis of the poetic - in a wide sense, encompassing music and dance. The roots of theatre are often identified in Ancient Greek tragedy and comedy. In that context, a link between the terms "theatre" and "theory" has been observed via the verb theorein (being spectator, behold) and its noun thea (view, spectacle). It might thus seem that theatre is first of all to be viewed, and that sound and listening are secondary. The following thoughts provide an additional view - if not a different understanding.
\end{abstract}

Keywords: poetry; theatre; hypotyposis; voice; sound.

\section{Ovid and Salmacis' voice}

Ovid's Metamorphoses, published in the first decade of the common era, are transformations on two levels. The fifteen books, covering the world's mythicized history from the creation of the cosmos to Julius Caesar, mostly describe transformations of mythological figures who are turned 
to stone, changed into a flower or, like Io, into a cow. In addition, Ovid does not just retell the received stories - mostly from Greek mythology - in Latin verse, but combines material from diverse sources and molds it into something new and different. All this is evident in the story of Hermaphroditus' encounter with the nymph Salmacis, which is singularly interesting for its striking description of the fusion of two beings, two subjects, two wills into one (Book IV, 271-388). The metamorphoses of this book are not told directly by the narrator but by figures that finally undergo transformation themselves, in this case into bats. The narrative is set in the house of King Minyas in Boeotia whose three daughters refuse to participate in the ceremonies of Bacchos - the Latin equivalent of Dionysos -, a new god recently arrived from Asia, questioning his divinity as Pentheus had done before in Thebes. While everyone else participates in the orgies outside, the three sisters stay home, spinning yarns, telling amazing stories. After two tales with tragic endings, the third of the sisters, Alcithoë, announces a captivating one that, she says, is new - and lovely (dulci).

She then describes the fate of the son of Hermes and Aphrodite, who carries the name of both mother and father ${ }^{1}$, and of the nymph Salmacis. Only some decades before (30 BCE at the latest), Diodorus of Sicily presents Hermaphroditos ${ }^{2}$ as having inherited not only the beauty but also the gender attributes of both parents, i.e. as being born androgynous $(1814,4.6 .5)$. The Ovidian transformation, on the other hand, tells a story that explains the god's androgyny: Alcithoë has Hermaphroditus being born a boy. The parents then entrust his education to naiads (source nymphs) in the caves of the mountain Ida (to the South-East of Troy on the Western shores of today's Turkey). At the age of fifteen, Hermaphroditus leaves his home to discover the world. His journey leads southwards to Lycia and then into Caria where he comes to a source (fons) called Salmacis. Often referred to as a "lake", this pond is the second ingredient used by Ovid: Alcithoë states that her story will give the missing explanation of why its waters have the well-known effect to effe-

1 "Mercurio puerum diva Cythereide natum / [...] cuius erat facies, in qua materque paterque / cognosci possent; nomen quoque traxit ab illis.” (Ovid, Met. 288-91). The text presupposes the reader's knowledge of the parents' Greek names Hermes and Aphrodite.

2 The latinized form "Hermaphroditus" will be used to refer to Ovid's character, "Hermaphroditos" to designate the deity in Greek mythology. 
minate men ${ }^{3}$. The pond, which serves as scenery for the ensuing action, is not an Ovidian invention as it is mentioned in non-fictional accounts ${ }^{4}$.

Upon first sight, Salmacis falls in love with the young god. She runs up to him and wants to kiss him, which he blushingly refuses, "for he knows love not yet." He threatens to leave, so she withdraws, inviting him to remain at her lake and hides behind a bush to observe him. He starts to undress until he is fully naked, approaches the water and tests its temperature with his toes before he launches into the waves, crawling through them with such grace as only Ovid's words can properly render. Salmacis cannot control herself and, quickly disrobed, fire in her eyes, she plunges into her pond, seizes and caresses him and tries everything to seduce him, but in vain. Since she does not succeed, she calls upon the gods to fulfil her desire: Let us be one forever! Some gods, not named at this point of the text, hear and fulfil her wish and merge the two bodies into one: «No more two are they, but a twofold form, not to be called a woman / nor a boy, appearing to be neither and yet both» (Ovid, Met.

3 "Unde sit infamis, quare male fortibus undis / Salmacis enervet tactosque remolliat artus, / discite. causa latet, vis est notissima fontis." (Ovid, Met. 285-87). It would be interesting to write a history of the highly controversial translations of this text, especially of the terms that describe the feminization of the male body, covering a semantic field from "débilitant" or "Verweichlichung" to relaxation or cultivation, but also of the "medicamen" that is finally used to enchant the pond, where translations vary from poison to healing medication (for details see Groneberg (2008, 94-102). Brookes More translates "learn how it enervates and softens the limbs of those who chance to bathe". Most modern translations, even newer ones from the end of the 20th century, are pejorative, but the negative judgment of feminization is old and can be found in authors even anterior to Ovid.

${ }^{4}$ Vitruvius (De arch. II, ch. VIII.11; written between 30 and 15 BCE) localized the source on the heights above the harbor of Halikarnassos (today's Bodrum), by nature formed "similar to a theatre curvature". On its middle height was situated one of the seven world wonders, the Mausoleum, named after Mausolus, died in 353 BCE, highly praised by Vitruvius for his architectural genius in building Halikarnassos. On top of the heights, Vitruvius describes in the middle a shrine of Mars containing a colossal statue of the wargod and on its right side "a temple to Venus and Mercury next to the source of Salmacis". He then argues that drinking from the source does not render sexually morbid ("venerio morbo") as it is believed. Stating that the water from this well "is clear and tastes excellent", it cannot be that it renders "soft and lewd" (molles et inpudicos). Its fame is rather due to wrong story-telling, the truth being that wild and cruel Barbarians who used to come down from the mountains to the source were "softened" in the sense of civilized, without coercion, by the cultivated behavior of the Greeks who resided there (ibid. VIII.12). Other sources are Ennius, fragm. 11; Strabon XIV.2,16; Plinius, Naturalis Historia XXXI.36; Cicero is one to use the epithet "effeminate" in this context in a morally depreciative way (Cicero, De off. I.61; see also I.14). 
IV, 378-9) ${ }^{5}$.

What follows is a description of the resulting creature's reaction, beginning with "him" looking down on himself, then raising the hands to the sky asking the gods for yet another favor with a voice that is not male anymore. The name "Hermaphroditus" is mentioned for the first and only time at this point where the description pivots from the visual to the acoustic, from what we see to what we hear:

So when he saw that the waves that he had entered as a man

Had made him a half-man and that his members had relaxed [mollita], Stretching out his hands, but with no more male a voice,

Hermaphroditus said [ait]: 'Give a present to your son who has the name of you both

You, Father and you, Birthgiver [genetrix]:

Whoever to this spring comes as a man, shall leave it

As half-man and, touching the waves, shall relax [mollescat] at once.'

Both parents being moved, they fulfilled the wish of their dimorphous son

And poured some medicine [medicamen] for the gender in the well.

(Ovid, Met. IV, 380-8) ${ }^{6}$

Here Alcithoës story ends. How to interpret this wish and its fulfillment? Is it a punishment, a tragedy, a bad ending as many modern translations render it? But why would the parents punish their son? How could the story told by Alcithoë be a "sweet" one if it ends badly? Above all: the voice calling for the magic charm is partly the nymph's who had her wish. Although this is not the question that concerns us primarily, let us state that the interpretation as a happy end is also an option. What is at stake is the relation, staged by Ovid in this fictional scene, of what is seen and what is heard. Clearly, a voice transmits more than semantics. We hear its gender. We identify a human voice as male or female, and sometimes as both or neither. And there is much more to a voice: it expresses states of the soul, emotion and will. We would like to know how the now androgynous Hermaphroditos utters the wish: wanting to share this bliss, full of joy, or condemning others to the same terrible fate, full of rage? Does the nymph speak in this voice, she who wanted to

${ }^{5}$ Translations are by the author unless otherwise mentioned.

${ }^{6}$ Reasons for a translation of the terms "mollire" and "mollescere" as "relaxing" are given in Groneberg (2008). See also More's translation "now his limbs relaxing in the stream”. This corresponds well with Hesiod's description of Eros being lysimelês (Theogonia 121). 
be united - if so: did she want it this way? Or does the young god speak in it, he who refused the sexual union, but might be fascinated by this result? Or is it a common will that speaks? But how to imagine that? Ovid leaves it open. The story ends with the open question of how two subjectivities may merge into one, how two opposed wills may speak as one.

What concerns us here is the following: in the description of the union, first we see, then we hear. While the static vision of their body is linked to the dominant male perspective, the voice with its temporal dimension, expressive of the soul, transcends this view and partakes of the female. In that voice, Salmacis is present as subject. The higher union, "more wondrous still", takes place in the soul, as another passage indicates, far from Book IV: «even more astounding are those liquids that are capable of changing not only the body but also the soul. Who has not heard of the obscene [obscenae] waves of Salmacis?» (Ovid, Met. XV, 316-20)

The fusion of two bodies is intriguing, but bears no conceptual or imaginary challenge. However, the fusion of two souls - nowadays we would say of two subjects and therefore of two wills - is much harder to imagine or to conceive, if it is conceivable at all... Even in Ovid, we do not enter the resulting creature's subjectivity. In any case, it is the voice that problematizes the possibility of such a metamorphosis of several wills into one.

\section{GREeK MYthology AND the Voiceless HeRmaphroditos}

The god Hermaphroditos is, apart from the mention by Diodorus, absent in Greek mythology, which gives rise to the question of whether he existed at all. Written testimony is very rare and consists of four or five engravings or fragments. To make a long research story short, there are none dating back before the $4^{\text {th }}$ century BCE. The pictorial sources are more telling: We learn from them that there is indeed an individual androgynous god (not only a type like the satyrs or maenads). Like Orpheus, Hermaphroditos is obviously a relatively new character, not to be found in Hesiod, who wrote his cosmo- and theogony several centuries before. His appearance is most likely explained as the fusion of his parents Hermes and Aphrodite who would figure, in archaic and classic times, as patrons of wedding ceremonies that included rites of clothes-swapping between men and women. Over time, the two deities 
seem to have been merged into one in such contexts. Hermaphroditos can thus be considered the "real", not only the nominal, fusion of the two gods in Greek mythology, appearing in the $4^{\text {th }}$ century BCE with regional variations: On Cyprus, Aphrodite's island, the resulting god was called Aphroditos. In phallocratic Attica, the "father" also appeared in the resulting name ${ }^{7}$. Hermaphroditos - or Aphroditos on Cyprus - thus represents the union of man and woman in marriage and is appealed to when it comes to finding the right partner for founding a home and a family, wearing only the veil of marriage and the staff of fertility. The ancient Hermaphroditos thus symbolizes the perfect union of man and woman - and not at all real intersexed persons that were, during several centuries in Ancient Greece and Rome, considered to be monsters and had to be killed ${ }^{8}$.

A statue is not a story, so the question emerges: why were there no stories told before Ovid? Why is there no poetry about Hermaphroditos in Greek mythology? The only comparable piece of poetry is to be found in Plato's Symposium, written around 385 BCE. As in Ovid's story, Plato does not speak directly, but sets up a fictional situation for stories to be told by several voices. In this case, comedy writer Aristophanes tells us in his eulogy of Eros what love amounts to: finding our other half in order to re-establish our lost unity and wholeness - later on in the text, this position will be explicitly refuted by the words of the fictional character Diotima, the only "female" voice present, in an account of her teaching given by Socrates. In this context - again a discourse of sexual love -, the term androgyny is used and linked to the relation of man and woman who are the result of the original androgynous gender being cut in two, now longing to be re-united. Ovid's story sounds like a far echo to this theme of love conceived as fusion with the desired one to regain lost completeness.

Let me propose an explanatory hypothesis: there might have been no ancient stories about Hermaphroditos for there was no interest in the reality of intersexed persons. The god rather symbolizes the union of woman and man in marriage, based on what we now call heteronormative practice. Intersexed persons were not only killed in reality, but also annihilated in the imaginary realm, replaced by a harmonious image in

${ }^{7}$ Around 300 BCE, Theophrastus explicitly identifies Hermaphroditos with Aphroditos (Hesychius, Dictionary I, s. v. Aphroditos) and mentions Hermaphrodite statues in his Characters (ch. 16.10, lines 20-24; written after 319).

${ }^{8}$ Further sources in Groneberg (2008). 
stone reinforcing gender dualism ${ }^{9}$.

If, on the other hand, we investigate intersex narratives of the $21^{\text {st }}$ century, we see the opposite endeavor to present and understand the situation of real intersexed persons. In these narratives, the presence of musicality is striking. It should be underlined that the matter here is finally one of gender, not of sex or love: we are invited to follow the lived experiences of persons that are not clearly only male or only female. Whereas many of the ingredients of these narratives in literature and film can be traced back to Antiquity (the link with the moon, Hermes, Venus, fertility, finding a partner, marriage, etc.), one theme is typically modern: the reconciliation of opposites, the question of how to resolve contradictions or deal with dualisms, and this implies a development over time which is characteristic for a narrative, for a story - or for music.

\section{Hegel's musical dialectics}

When Hegel states that sculpture is the highest art form in Ancient Greece, and that Ancient Greek culture on the whole, including drama, is "statuary", he argues in an evolutionary line of thought (Hegel 1975, III.2.1.1-3). What he calls "classical" art shows the divine as being most properly present in human form, and for that purpose, sculpture is the perfect art. But it is a higher truth that the divine is only properly found in the mind (Geist) with its subjective, individual and emotional side mind is motion, it is subjective and it is not only cognitive but also feeling. Marble is not appropriate to express this, as little as only "seeing" Hermaphroditus' androgynous body is. Hence, art calls for the antithesis of sculpture, it calls for the voice or, as Hegel states it: it calls for music with its temporal development and its emotional power and "interiority" (III.3.2.1, Innerlichkeit).

Following this line of thought, mind or soul means essentially being alive; and life implies contradictions and dealing with or even overcoming them. Therefore, a temporal development is called for and we might be tempted to say: a story. In her analysis of what happens on stage, Mary Overlie (for reasons linked to the time of her writing) decided to talk of the viewpoint "story" although she considered it "far more accurate" to speak of "logic", even asking to "accept the two labels as interchangeable"

\footnotetext{
${ }^{9}$ Details in Groneberg (2016).
} 
(2016, 43ff.). Let us honor this approach and talk of a temporal development following a certain logic (be it narrative or musical or otherwise) in order to include post-dramatic, post-narrative or physical theatre, for "story" is a term generally associated with words.

The described opposition of the statuary and the temporal are part of a long discourse we inherited over the centuries. The task here is not to judge if this conception is right or a cultural phantasma. What is important to see is that it is still active, for example in the construction of plots for musicals, films or novels. Most of the contemporary intersex narratives not only contain striking references to music - like the intersexed protagonists of the stories being musicians and struggling with their contradictory sides using their music - but develop the story itself in a musical way. Other plots however do not, and their narration may be characterized as statuary, refusing any reconciliation, as is the case in the Draesner's "Intersex"-novel Mitgift (Dowry) that underlines the extremes, refusing an outcome other than the death for what some call "the monster": "only on representations of statues, the hermaphrodites [orig. Zwitter] seemed to be distant enough for Aloë [the hermaphrodite's sister] in order to be considered in peace» $(2002,229) 10$.

The statue - or a photography - can be considered in safe distance: we do not have to enter the subjectivity of the represented person as we do when we enter his or her story and listen to his or her voice.

\section{GUÉNOUN'S THEATRE AS HYPOTYPOSIS OF POETRY}

Up to this point, we have dealt with literary texts only, also with some rites and pictorial representations of mythological figures, but mainly with poetry. Aristotle says about poetry «that it is more philosophical and more noble than history: poetry expresses the general, history the particular» (1932, ch. 9, 1451 b5-7) In this understanding, Plato is more philosophical than Xenophon with his endeavor to stay close to the historical Socrates. Plato used the historical material, and he used Socrates, to forge some insights that are beyond historic reality. And Ovid is more philosophical than Diodorus for he also expressed something striking that is, in this case of mythological creatures, subdued to criteria differing clearly from those of historical accuracy.

${ }^{10}$ In Mitgift, we share Aloë's experience whose hermaphroditic sister remains objectivized. 
Aristotle talks about tragedies at this point, but the statement applies to all poetry, including epopees, lyrical poetry and what we would call today literature in general, but also dance and music (Ibid, ch.1). This is important to consider: there can be poetry without words and I suggest to follow this wide conception in order to include the poetic moments on stage that do not need words ${ }^{11}$.

If there is this general truth in poetry, a truth that is neither scientific nor historical, but about human action with its free will and contingency, and if all this demands temporal development, it seems plausible to assume that this kind of truth demands first of all to be told or to be listened to, as is the case with myths in times of oral transmission. But even if we listen (or read), we see and hear what is described. Ovid staged his stories somewhere: he created an imaginary setting, the source of Salmacis, for the fusion of the god with the nymph, and we also listen to the voice travelling from the waves to the sky. But then, of course, what is given "to see" and "to hear" is still imaginary. What is it that ushers poetry onto the real stage?

In a philosophical attempt to understand what theatre is and does, Denis Guénoun develops the idea that theatre is essentially poetry put before the eye. He uses the term hypotyposis, a rhetorical concept meaning the presentation of something in a realistic, lively and striking way $(2018,173)$, leaving its mark unforgettably in the minds of the beholders. Poetry wants to strike and, according to Guénoun, theatre is the realization of this inherent will of poetry in staging a spectacle for our eyes. ${ }^{12}$ Poetry was first of all something to be listened to, something recited or sung by the poets themselves or the rhapsodes. Let us not forget that the Iliad is a big poem, as well as the Mababharata and other myths, and that all tragedies and comedies were written in verse. If theatre evolved from improvisational elements in the recitations of these poems (Aristotle 1932, 1448b25-1449a30) that carry in themselves the challenge to strike us, this supports the assumption that something to be listened to was finally given to be watched as well. We might thus conceive of the movement from poetry to theatre as from listening (to the poem) to watching (the spectacle). I would like to push this analysis one step further by integrating the fundamental importance of sound

${ }^{11}$ Cf. the marvelous description of such a poetic moment in Guénoun $(2018,171)$.

${ }^{12}$ The Greek term for spectacle, representation or show, also used by Aristotle, is opsis.

Geography Notebooks - 4 (2021) 1

https://www.ledonline.it/Geography-Notebooks/ 
and music ${ }^{13}$.

\section{The Fusion}

Even if the poem needs first of all to be listened to, we finally see what Hermaphroditos sees, and hear the wish that is sent to the heavens. So seeing and hearing are already both present in poetry, of course only in our minds. But this urges to conceive of the movement of hypotyposis differently: not as putting before the eye what before was only heard, but as striking our real senses, our real eyes and ears with what before was only seen and heard in our imagination. This slight shift has a certain advantage: it allows for a proper account of that element so easily neglected when we speak of theatre: of the whole acoustic dimension, be it music or sound in general ${ }^{14}$.

This shift permits to account for this element so important to Hegel as antithesis giving room to the subject's experience (like expressed in Salmacis' voice) amidst what can be observed objectively (like the view of Hermaphroditus' body); important enough for Nietzsche to develop the birth of theatre out of the spirit of music; so omnipresent in intersex narratives as a means to deal with oppositions; so important to defenders of total art from Schiller to Wagner who miss this emotional element in modern theatre. We know that Greek tragedy or comedy was not only put before the eyes of the spectators - it was also enhanced by the sounds of music and by the rhythm of dance, it was an experience to be felt. Theatre meant to move the public, a purpose to which music was best suited.

Following Plato, Aristotle knew this too well. Although in his Poetics he initially treats dance and music also as mimêseis (ch.1), he then discusses mimêsis only in relation to images, speaking of the pleasure we find in looking at pictures (ch.4). A discussion of the mimetic properties of music is only to be found in his Politics, in the part on education (Book VIII, ch. 5). There, we learn that music not only touches the soul profoundly, tunes our mood and enthuses us, it can also form the character. Only music (harmony and rhythm) contains immediate expressions

${ }^{13}$ This approach may have been inspired by a late analysis of the foundational role of sound and music for any art by Philippe Lacoue-Labarthe (2005).

${ }^{14}$ Some modern authors trace the origin of music, but also of theatre, and of arts in general, back to our prenatal sound experience in the womb (Kirkkopelto 2020, 157-162; Lacoue-Labarthe 2005). 
(mimêma; 1340a38) of character traits and virtues like courage, being directly similar (bomoioma; 1340a28) to them, more than any visual form or color could, for the latter is only a sign of it (sêmeion, 1340a33)! Like Plato, he considers music a major educative tool - and powerful enough to be submitted to censure - and follows his teacher in contending the role of the poets as educators, evacuating music from a treatment in the Poetics, reserving it for the philosopher's political theory.

This shift I would propose to apply to Guénoun's ingenious analysis: theatre puts poetry not only before the eye but before our senses in general. Sound is not only transporting semantics, it transports feelings: sound moves. And music exploits this potential. What we lose by neglecting sound is not to be underestimated: sound connects to the soul directly, be it in the imagination or passing through our ears.

\section{ConClusion}

A sound can express the state of a soul (often called the "interior") with its subjectivity, including emotions, moods and its will, and does so sometimes more directly, even without words, than anything that can be seen. Truths of mind and life are properly expressed in temporal development and demand the integration of the subjective view that enters into conflict with the objective. As the analysis of Ovid's narration of Hermaphroditos and Salmacis shows, voice and narrations, if read aloud or only imagined, but also music, both developing over time, are the media to not only tell stories but also express feelings and wills. This moving power of sound and music is uncontested. Poetry thus also makes us listen, aside from showing us things. Furthermore, some things, especially wills, might even not be understood through sight alone and require to be heard. On the other hand, we are visual beings, as is confirmed by all the visual metaphors for knowledge and understanding. So even if some poetic truths demand for their proper expression a temporal development in order to be heard, poetry challenges us to bring it also before our eyes. Thus, let us extend Guénoun's proposal to saying that poetry has the inherent will to bring its contents before our eyes and ears, to materialize it in space and time such that it can be experienced by our major senses with the purpose to strike and move us, and for that, we need to watch and to listen. That is theatre. 


\section{REFERENCES}

ANCIENT SOURCES

Aristotle, Poetics. 1932. Aristotle in 23 volumes, vol. 23. Cambridge: Harvard University Press; London: William Heinemann Ltd [transl. by W.H. Fyfe].

Aristotle, Politics. 1957. Aristotle's Politica. Oxford: Clarendon Press [transl. by W. D. Ross].

Diodorus of Sicily, History. 1814. The Historical Library of Diodorus of Sicily in 15 Books. London: M’Dowall [transl. by George Booth]. [30.6.2020]. http://data.perseus.org/texts/urn:cts:greekLit:tlg0060.tlg001

Hesiod, Theogony. 2017. Theogony and Works and Days: A New Critical Edition, edited by Kimberly Johnson. Evanston, Illinois: Northwestern University Press.

Hesychius of Alexandria, Dictionary. 2018. Hesychii Alexandrini lexicon: vol. I: $A-\Delta$, edited by Kurt Latte and Ian Campbell Cunningham. Berlin; Boston: De Gruyter.

Ovid, Met. (1922) 1994. Ovidi Nasonis Metamorphoseon libri quindecim/Metamorphosen in fünfehn Büchern von P. Ovidius Naso. Edited by Michael von Albrecht. Stuttgart: Reclam [transl. by Brookes More. Boston: Cornhill].

Plato, Symposium. 2008. Cambridge: Cambridge University Press [transl. by M.C. Howatson].

Theophrastus, Characters. 2003. Cambridge MA: Harvard University Press [transl. by Jeffrey Rusten].

Vitruvius, De arch. 1912. Vitruvii De architectura libri decem, edited by Fritz Krohn. Leizipig: Teubner. [30.6.2020] http://data.perseus.org/texts/ urn:cts:latinLit:phi1056.phi001.

1914. Ten Books on Architecture. Transl. by Morris Hicky Morgan. Cambridge MA: Harvard University Press. [30.6.2020] http://data.perseus.org/texts/urn:cts:latinLit:phi1056.phi001.perseus-eng1.

MODERN LITERATURE

Groneberg, M. 2008. "Mythen und Wissen zur Intersexualität”. In Intersex Geschlechtsanpassung zum Wobl des Kindes?, edited by Michael Groneberg and Kathrin Zehnder, 83-145. Fribourg: Academic Press.

Groneberg, M. 2016. "Hermaphrodite's Voice: Dealing with the Either-Or Attitude in Science, Law, and the Arts". In Transgender and Intersex: Theoretical, Practical and Artistic Perspectives, edited by Stefan Horlacher, 225-252. New York: Palgrave Macmillan.

Draesner, U. 2002. Mitgift. München: Luchterhand. 
Guénoun, D. 2018. “Théâtre et poésie: propositions”. In Penser la scene, edited by Michael Groneberg, 169-181. Lausanne: Études de Lettres.

Hegel, G.W.F. 1975. Aesthetics. Lectures on Fine Art 2 vols. Oxford: Clarendon Press [transl. by T.M. Knox].

Kirkkopelto, E. 2008. Le théâtre de l'expérience. Contributions à la théorie de la scène. Paris: Presses de l'université Paris-Sorbonne.

Kirkkopelto, E. 2020. "La scène comme antichambre de la vie et de la mort". In Philosopbies du jeu théâtral, edited by Michael Groeneberg, 155-172. Lausanne: Études de Lettres.

Lacoue-Labarthe, P. 2005. Le chant des muses: petite conférence sur la musique. Lonrai: Bayard.

Overlie, M. 2016. Standing in Space. The Six Viewpoints Theory \& Practice. Billings, Montana: Fallon Press. 
